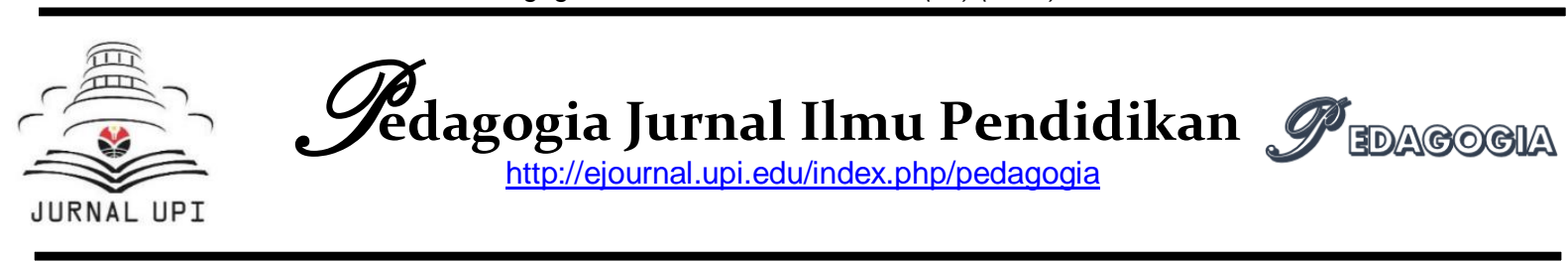

\title{
Meningkatkan Kemampuan Eksplorasi Siswa Melalui Pembelajaran Learning Cycle
}

\author{
Nur Kholis \\ Sman 1 Pusakanagara Subang \\ weswey northgate@yahoo.com
}

\begin{abstract}
Seeing the learning outcomes of students at SMAN 1 Pusakanagara on geographic subjects is not satisfactory when viewed from the achievement of student competencies. With the aim of improving student learning outcomes encourage authors to conduct this research. However, the substance of this research is how to improve the ability of students to be exploited, because learning through direct experience experienced by students will provide meaning in the learning process. The use of the learning cycle model is one of the efforts to improve these competencies. By using action research methods obtained data in the form of a percentage graph that shows the learning outcomes of students. From the results of the study in the learning process using the learning cycle approach, the results obtained in the form of an average value of students increased significantly, namely from the average initial value is 4.5 in the first cycle to 6.3 and in the second cycle rose to 7.9. The results of this study prove that the exploration ability of students through learning cycle learning at SMAN 1 Pusakanagara can improve students' abilities.
\end{abstract}

Keywords: Learning Cycle, Exploration, Geographic Subjects

\begin{abstract}
Abstrak
Melihat hasil belajar pada peserta didik di SMAN 1 Pusakanagara pada mata pelajaran geografi belum memuaskan jika dilihat dari ketercapaian kompetensi peserta didik. Dengan tujuan untuk memperbaiki hasil belajar peserta didik mendorong penulis untuk melakukan penelitian ini. Namun yang menjadi substansi dalam penelitian ini adalah bagaimana cara meningkatkan kemampuan eksplorasi peserta didik dapat ditingkatkan karena dengan cara belajar melalui pengalaman langsung yang dialami oleh peserta didik akan memberikan makna dalam proses belajar mengajar. Penggunaan model learning cycle menjadi salah satu upaya untuk meningkatkan kompetensi tersebut. Dengan menggunakan metode tindakan kelas diperoleh data berupa grafik persentase yang menunjukan hasil belajar peserta didik. Dari hasil penlitian pada proses pembelajaran dengan menggunakan pendekatan learning cycle didapatkan hasil berupa nilai rata-rata peserta didik terjadi kenaikan yang signifikan, yaitu dari rata-rata nilai awal adalah 4,5 naik di siklus pertama menjadi 6,3 dan di siklus kedua naik menjadi 7,9. Hasil penelitian ini membuktikan bahwa kemampuan eksplorasi siswa melalui pembelajaran learning cycle di SMAN 1 Pusakanagara dapat meningkatkan kemampuan peserta didik.
\end{abstract}

Kata Kunci: Learning Cycle, Eksplorasi, Mata Pelajaran Geografi

\begin{tabular}{l}
\hline Article Info \\
\hline Naskah Diterima: \\
2019-03-06 \\
Naskah Direvisi: \\
2019-04-04 \\
Naskah Disetujui: \\
2019-04-25 \\
\hline
\end{tabular}

Kata Kunci: Learning Cycle, Eksplorasi, Mata Pelajaran Geografi 


\section{A. PENDAHULUAN}

Sekolah merupakan tempat bagi siswa untuk meningkatkan kemapuan dalam berpikir, dari proses berpikir yang sederhana menuju sesuatu yang abstrak dan komples. Sebagai suatu entitas yang akan meciptakan output yang memiliki kemampuan berpikir logis, kritis serta dinamis. Sekolah harus memiliki sistem yang terbuka dalam memandang suatu perubahan, karena disuatu perubahan akan dibarengi dengan sesuatu yang latens dan dapat berdampak positif ataupun sebaliknya. Hal ini terjadi karena arus informasi yang disebabkan oleh globalisasi akan menciptakan akulturasi dan asimilasi yang lambat laun akan menggerus budaya lokal. Peran sekolah diharapkan dapat menjadi bangunan yang tidak hanya menciptakan manusia yang berakal saja tetapi juga memiliki karakter yang kuat sesuai dengan kepribadian bangsa.

Revolusi industri yang mengarah pada Indtusri 4.0 telah memberi bentuk pembelajaran yang terintegrasi dengan kebutuhan kerja. Proses pembelajaran konvensional pun bertransformasi pada bentuk pembelajaran yang serba komputerisasi. Siswa merupakan makhluk biologis yang dibekali dengan kemampuan berpikir yang terbentuk secara maternal ataupun dibentuk oleh lingkungan. Dalam kecerdasaan maternal siswa tidak dapat dipandang secara homogen tetapi memiliki bakat dan minat yang berbeda. Guru harus dapat membaca satu per satu kemampuan siswa agar bisa membuat model pembelajaran yang dapat menyentuh motivasi dan keinginan eksplorasi siswa sehingga siswa dapat meningkatkan hasil belajar dan mendorong persaingan positif untuk dapat berprestasi. Mekanisme yang rumit ini harus diisi dan dijalankan oleh individu-individu yang memiliki visi perubahan yang baik. Komponen sekolah yang terdiri dari bangunan, kepala sekolah, guru, dan staf pendidik yang berdedikasi serta memiliki integritas kerja yang profesional.

Berkaitan dengan itu, Pemerintah telah melakukan berbagai penataan dalam sistem standarisasi pendidikan, seperti yang dituangkan dalam Peraturan Pemerintah (PP) Republik Indonesia No 19 tahun 2005 Tentang Standar Nasional Pendidikan (SNP) dan PP Nomor 32 Tahun 2013 Tentang Perubahan atas Peraturan Pemerintah No 19 Tahun 2005 Tentang Standar Nasional Pendidikan. Dalam kedua peraturan tersebut dikemukakan bahwa "Standar Nasional Pendidikan adalah kriteria minimal tentang sistem pendidikan di seluruh wilayah Indonesia" (Mulyasa, 2004). Standar Nasional Pendidikan bertujuan menjamin mutu pendidikan nasional dalam rangka mencerdaskan kehidupan bangsa dan membentuk watak serta peradaban bangsa yang bermartabat.

Upaya Pemerintah tersebut merupakan bentuk untuk meningkatkan mutu pendidikan di Indonesia dengan berupaya menyusun sebuah standar yang dapat dicapai oleh satuan pendidikan di Indonesia. Hal ini penting dilakukan karena sebuah sistem harus dibangun dengan sebuah dasar hukum sehingga tujuan yang hendak dicapai dapat berjalan dengan baik. Sesuai dengan standar pendidikan nasional menyatakan bahwa seorang pendidik harus memiliki kualifikasi minimal sarjana yang sesuai dengan bidang pelajaran yang diampu dengan bidang mata pelajaran yang diajarkan. Kemampuan profesional pendidik dapat menerapkan berbagai strategi ataupun model pembelajaran yang sesuai dengan kebutuhan dan kemampuan belajar siswa. Bruner (dalam Dahar, Ratna Wilis, 2006) rupanya tidak mengembangkan suatu teori belajar yang sistematis. Hal yang penting baginya ialah cara bagaimana orang memilih, mempertahankan, dan 
mentransformasi informasi secara aktif, inilah inti belajar menurut Bruner. Oleh karena itu, Bruner memusatkan perhatiannya pada masalah apa yang dilakukan manusia dengan informasi yang diterimanya dan apa yang sesudah dilakukannya sesudah memperoleh informasi yang diskret itu mencapai pemahaman yang memberikan kemampuan padanya.

Guru pada kegiatan belajar mengajar di dalam kelas akan menyampaikan informasi yang parsial kepada siswa, selanjutnya tugas siswa adalah untuk mencari informasi yang utuh berkaitan dengan isi materi pelajaran. Setelah memperoleh informasi yang utuh kemudian secara berkelompok siswa akan mengelaborasi informasi yang akan ditampilkan dan disampaikan kepada rekan-rekanya di dalam kelas. Lebih lanjut Bruner (dalam Dahar, Ratna Wilis, 2006) mengemukakan empat tema pendidikan. Tema pertama mengemukakan pentingnya arti struktur pengetahuan. Kurikulum hendaknya mementingkan struktur pengetahuan. Hal ini perlu sebab dengan struktur pengetahuan, kita menolong para siswa untuk melihat bagaimana fakta-fakta yang kelihatannya tidak memiliki hubungan dapat dihubungkan satu dengan yang lain, dan pada informasi yang telah mereka miliki.

Tema kedua ialah tentang kesiapan belajar. Kesiapan belajar yang baik, siswa da patmengikuti pembelajaran dengan aktif dan mudah menyerap pelajaran yang disampaikan ketika dalam proses pembelajaran (Mulyani, 2013). Kesiapan belajar terdiri atas penugasan keterampilan yang lebih sederhana yang dapat mengizinkan seseorang untuk mencapai keterampilan yang lebih tinggi. Tema yang ketiga menekankan nilai intusi dalam proses pendidikan. Dengan instusi, yang dimaksudkan oleh Bruner adalah teknik-teknik intelektual untuk sampai pada formulasi tentatif tanpa melalui langkahlangkah analitis untuk mengetahui apakah formulasi itu merupakan kesimpulan yang sahih atau tidak. Hal ini yang dikemukakan oleh Bruner ialah semacam educated guess yang kerap kali digunakan oleh para ilmuwan, artis, dan orang-orang kreatif lainnya.Tema keempat dan terakhir ialah tentang motivasi atau keinginan untuk belajar dan cara-cara yang tersedia pada para guru untuk merangsang motivasi itu. Pengalaman pendidikan yang merangsang motivasi ialah pengalaman di mana para siswa berpartisipasi secara aktif dalam menghadapi alamnya. Menurut Bruner, pengalaman belajar semacam ini dapat dicontohkan oleh pengalaman belajar penemuan yang intuitif dan implikasi ini akan dibahas dalam bagian-bagian yang akan datang.

Dalam ketegori ini peserta didik tidak bisa dipandang homogen, bakat dan minat yang melekat pada peserta didik tidak bijak jika diukur dengan menggunakan satu atau dua indikator saja. Seperti yang diungkapkan Howard Gardner (dalam Ruhyat, 2018) Howard Gardner menilai guru yang secara berlebihan hanya menilai kecerdasan linguistik dan matematik saja dapat menghambat bentuk kecerdasan yang lain. Banyak siswa yang gagal menunjukkan prestasi akademiknya karena dikategorikan dalam penghargaan yang rendah atau low esteem dan kemampuan mereka (yang sebenarnya) menjadi tidak terlihat/muncul/terjadi dan hilang dari sekolah dan bahkan dari masyarakat secara luas

Pemaparan yang telah disampaikan di atas memberi suatu pandangan baru bagi penulis dan memberi semangat untuk mencoba model pembelajaran learning cycle untuk meningkatkan kemampuan eksplorasi siswa pada mata pelajaran Geografi di SMAN 1 Pusakanagara. Hal ini dilakukan untuk memberi suasana yang berbeda pada proses belajar mengajar 
sehingga diharapkan pada akhirnya dapat meningkatkan hasil belajar siswa.

\section{B. TINJAUAN PUSTAKA}

\section{Pengertian Learning Cycle}

Siklus Belajar (Learning Cycle) atau dalam penulisan ini disingkat LC adalah suatu model pembelajaran yang berpusat pada pebelajar (Student Centered). LC merupakan rangkaian tahap-tahap kegiatan (fase) yang diorganisasi sedemikian rupa sehingga pebelajar dapat menguasai kompetensi-kompetensi yang harus dicapai dalam pembelajaran dengan jalan berperanan aktif.

LC pada mulanya terdiri dari fasefase eksplorasi (Exploration), pengenalan konsep (Concept Introduction), dan aplikasi konsep (Concept Application) (Karplus dan Their dalam Renner et al, 1988). Pada tahap eksplorasi, pebelajar diberi kesempatan untuk memanfaatkan panca inderanya semaksimal mungkin dalam berinteraksi dengan lingkungan melalui kegiatan-kegiatan seperti praktikum, menganalisis artikel, mendiskusikan fenomena alam, mengamati fenomena alam atau perilaku sosial, dan lain-lain. Dari kegiatan ini diharapkan timbul ketidakseimbangan dalam struktur mentalnya (Cognitive Disequilibrium) yang ditandai dengan munculnya pertanyaan-pertanyaan yang mengarah pada berkembangnya daya nalar tingkat tinggi (High Level Reasoning) yang diawali dengan kata-kata seperti mengapa dan bagaimana (Dasna dan Rahayu, 2005). Munculnya pertanyaanpertanyaan tersebut sekaligus merupakan indikator kesiapan siswa untuk menempuh fase berikutnya, fase pengenalan konsep. Pada fase ini diharapkan terjadi proses menuju kesetimbangan antara konsepkonsep yang telah dimiliki pebelajar dengan konsep-konsep yang baru dipelajari melalui kegiatan-kegiatan yang membutuhkan daya nalar seperti menelaah sumber pustaka dan berdiskusi. Pada tahap ini pebelajar mengenal istilahistilah yang berkaitan dengan konsepkonsep baru yang sedang dipelajari. Pada fase terakhir, yakni aplikasi konsep, pebelajar diajak menerapkan pemahaman konsepnya melalui kegiatan-kegiatan seperti problem solving (menyelesaikan masalah-masalah nyata yang berkaitan) atau melakukan percobaan lebih lanjut. Penerapan konsep dapat meningkatkan pemahaman konsep dan motivasi belajar, karena pebelajar mengetahui penerapan nyata dari konsep yang mereka pelajari. Implementasi LC dalam pembelajaran menempatkan guru sebagai fasilitator yang mengelola berlangsungnya fase-fase tersebut mulai dari perencanaan (terutama pengembangan perangkat pembelajaran), pelaksanaan (terutama pemberian pertanyaan-pertanyaan arahan dan proses pembimbingan) sampai evaluasi. Efektivitas implementasi LC biasanya diukur melalui observasi proses dan pemberian tes. Jika ternyata hasil dan kualitas pembelajaran tersebut ternyata belum memuaskan, maka dapat dilakukan siklus berikutnya yang pelaksanaannya harus lebih baik dibanding siklus sebelumnya dengan cara mengantisipasi kelemahan-kelemahan siklus sebelumnya, sampai hasilnya memuaskan.

LC tiga fase saat ini telah dikembangkan dan disempurnakan menjadi 5 dan 6 fase. Pada LC 5 fase, ditambahkan tahap engagement sebelum exploration dan ditambahkan pula tahap evaluation pada bagian akhir siklus. Pada model ini, tahap concept introduction dan concept application masing-masing diistilahkan menjadi explaination dan elaboration. Karena itu LC 5 fase sering dijuluki LC 5E (Engagement, Exploration, Explaination, Elaboration, dan Evaluation) (Lorsbach, 2002). Pada LC 6 fase, ditambahkan tahap identifikasi tujuan 
pembelajaran pada awal kegiatan (Johnston dalam Iskandar, 2005). Tahap engagement bertujuan mempersiapkan diri pebelajar agar terkondisi dalam menempuh fase berikutnya dengan jalan mengeksplorasi pengetahuan awal dan ide-ide mereka serta untuk mengetahui kemungkinan terjadinya miskonsepsi pada pembelajaran sebelumnya. Dalam fase engagement ini minat dan keingintahuan (curiosity) pebelajar tentang topik yang akan diajarkan berusaha dibangkitkan. Pada fase ini pula pebelajar diajak membuat prediksi-prediksi tentang fenomena yang akan dipelajari dan dibuktikan dalam tahap eksplorasi. Pada fase exploration, siswa diberi kesempatan untuk bekerja sama dalam kelompokkelompok kecil tanpa pengajaran langsung dari guru untuk menguji prediksi, melakukan dan mencatat pengamatan serta ide-ide melalui kegiatan-kegiatan seperti praktikum dan telaah literatur. Pada fase explanation, guru harus mendorong siswa untuk menjelaskan konsep dengan kalimat mereka sendiri, meminta bukti dan klarifikasi dari penjelasan mereka, dan mengarahkan kegiatan diskusi. Pada tahap ini pebelajar menemukan istilahistilah dari konsep yang dipelajari. Pada fase elaboration (extention), siswa menerapkan konsep dan ketrampilan dalam situasi baru melalui kegiatankegiatan seperti praktikum lanjutan dan problem solving. Pada tahap akhir, evaluation, dilakukan evaluasi terhadap efektivitas fase-fase sebelumnya dan juga evaluasi terhadap pengetahuan, pemahaman konsep, atau kompetensi pembelajaran melalui problem solving dalam konteks baru yang kadang-kadang mendorong pembelajar melakukan investigasi lebih lanjut. Berdasarkan tahapan-tahapan dalam metode pembelajaran bersiklus seperti dipaparkan di atas, diharapkan siswa tidak hanya mendengar keterangan guru tetapi dapat berperan aktif untuk menggali dan memperkaya pemahaman mereka terhadap konsep-konsep yang dipelajari. Berdasarkan uraian di atas, LC dapat dimplementasikan dalam pembelajaran bidang-bidang sain maupun sosial.

\section{Tahapan Pelaksanaan Learning Cycle}

Learning cycle merupakan salah satu model pembelajaran dengan pendekatan konstruktivis yang pada mulanya terdiri atas tiga tahap, yaitu: eksplorasi (exploration), menjelaskan (explanation), dan memperluas (elaboration/extention), yang dikenal dengan learning cycle 3E. Pada proses selanjutnya, tiga tahap siklus tersebut mengalami perkembangan menjadi lima tahap, yaitu pembangkitan minat/mengajak

(engagement), eksplorasi/menyelidiki (exploration), menjelaskan (explanation), memperluas (elaboration/extention), dan evaluasi (evaluation), sehingga dikenal dengan learning cycle 5E (Kurnazz. 2008).

Engagement (mengajak), yaitu fase yang bertujuan mempersiapkan diri siswa agar terkondisi dalam menempuh fase berikutnya dengan jalan mengeksplorasi pengetahuan awal dan ide-ide mereka, serta untuk mengetahui kemungkinan terjadinya miskonsepsi pada pembelajaran sebelumnya. Dalam fase engagement ini minat dan keingintahuan siswa tentang topik yang akan dipelajari berusaha dibangkitkan. Siswa juga diajak membuat prediksi-prediksi tentang fenomena yang akan dipelajari dan dibuktikan dalam tahap eksplorasi.

Exploration (menyelidiki), pada fase ini siswa diberi kesempatan untuk bekerjasama dalam kelompok-kelompok kecil tanpa pengajaran langsung dari guru untuk menguji prediksi, melakukan dan mencatat pengamatan serta ide-ide melalui kegiatan-kegiatan seperti praktikum dan telaah literatur. 
Exlaination (menjelaskan), dalam fase ini guru mendorong siswa untuk menjelaskan konsep dengan kalimat mereka sendiri, meminta bukti dan klarifikasi dari penjelasan mereka, dan mengarahkan kegiatan diskusi. Pada tahap ini siswa menemukan istilah-istilah dari konsep yang dipelajari.

Elaboration/Extention (memperluas), yaitu siswa menerapkan konsep dan keterampilan dalam situasi baru melalui kegiatan-kegiatan seperti praktikum lanjutan dan problem solving.

Evaluation (evaluasi), dilakukan evaluasi terhadap efektivitas fase-fase sebelumnya dan juga evaluasi terhadap pengetahuan, pemahaman konsep atau kompetensi siswa melalui problem solving dalam konteks baru yang kadang-kadang mendorong siswa melakukan investigasi lebih lanjut.

\section{METODE PENELITIAN}

Penelitian ini dilaksanakan di kelas $X$ IPA 1 SMAN 1 Pusakanagara. Penelitian Tindakan Kelas ini dilaksanakan melalui dua siklus untuk melihat peningkatan meningkatkan kemampuan eksplorasi peserta didik kelas $X$ IPA 1 SMAN 1 Pusakanagara melalui metode Learning cycle dalam proses pembelajaran di kelas. Setiap siklus PTK terdiri dari perencanaan, implementasi, pengamatan, dan refleksi. Hasil dari refleksi menjadi masukan pada perencanaan kembali untuk siklus berikutnya.

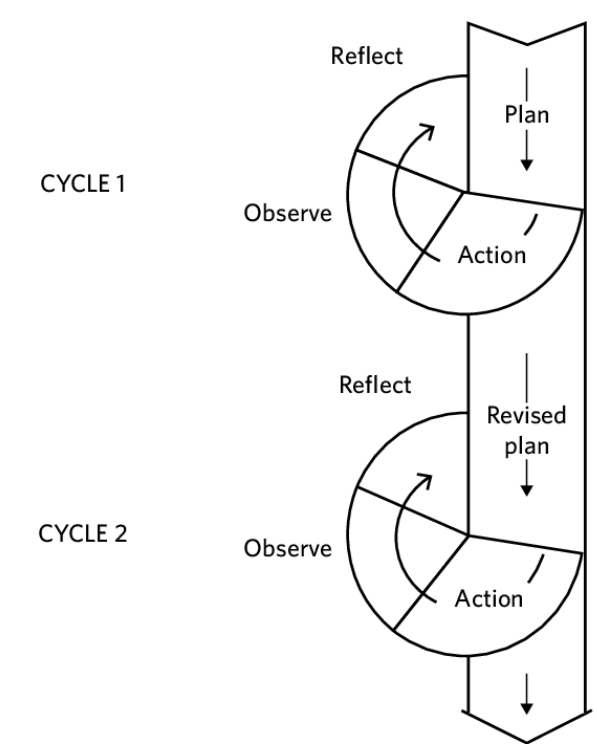

Gambar. 1 The Action Research Spiral (Kemmis, S., McTaggert, R dalam Bruns 2010)

Teknik pengumpulan data yang digunakan pada penelitian ini adalah tes, observasi atau pengamatan, dan wawancara kepada siswa untuk mengetahui persepsi dan kesan terhadap perlakuan pembelajaran.

\section{HASIL DAN PEMBAHASAN}

Refleksi merupakan kajian secara menyeluruh tindakan yang telah dilakukan berdasarkan data yang telah terkumpul, kemudian dilakukan evaluasi guna menyempurnakan tindakan. Refleksi menyangkut analisis, sintesis, dan penilaian terhadap hasil pengamatan atas tindakan yang dilakukan (Hopkin, dalam Arikunto, dkk, 2006).

\section{Hasil yang diperoleh dari tes prestasi belajar siklus Pertama}

Berdasarkan data yang yang diperoleh menunjukan nilai dari pre-test dan nilai post-test yang dikumpulkan oleh siswa kelas $X$ IPA 1 SMAN 1 Pusakanagara pada siklus I dapat dihitung dengan cara sebagai berikut. 
Nilai Rata-rata Pre-test

$\underline{X 0} \underline{189}=4,6$

$\mathrm{N} 41$

Nilai Rata-rata Sesi 1

$\underline{\mathrm{X} 1} \underline{231}=5,7$

$\mathrm{N} 41$

Nilai Rata-rata Sesi 2

$\underline{\mathrm{X} 2} \underline{278}=6,7$

N 41

Nilai total Rata-rata pada siklus pertama adalah

$\frac{X 1+X 2}{2}=\frac{5.7+6.9}{2}=\frac{12.6}{2}=6.3$

Untuk rekapitulasi hasil penelitian ini akan disampaikan sekaligus pada akhir analisis refleksi siklus kedua. Untuk hasil analisis pengamatan guru dan pengamatan siswa terhadap kebenaran pelaksanaan pembelajaran dengan model learning cycle. Untuk kedua hasil pengataman tersebut dapat disampaikan sebagai berikut. 1) pengamatan oleh guru berupa catatan kesalahan peneliti pada saat melaksanakan proses pembelajaran learning cycle, hal ini menjadi masukan yang sangat berharga untuk perbaikan pada siklus selanjutnya, untuk hal ini lebih lengkapnya dapat dilihat pada pembahasan. 2) untuk pengamatan yang dilakukan oleh kepala sekolah yang ada pada lampiran 6 , sudah terlihat tim yang mampu, tim yang belum mampu, sudah jelas menunjukkan keaktifan, keuletan, kreativitas, mencari hal-hal penting yang ditugaskan, menunjukkan kemampuan aktivitas, kritis, betul siswa yang giat belajar dan bukan guru yang giat mengajar, kemampuan menunjukkan konsep diri, kecepatan menanggapi tuntutan, kemampuan menelorkan kesimpulan-kesimpulan. Jumlah semua skor siswa pada pre-test adalah 189, dan pada jumlah skor pada sesi 1 adalah 231, sedangkan skor pada sesi 2 adalah 278, setelah dirata-ratakan maka skor yang diperoleh adalah 4,5 untuk nilai pre-test, 5,7 untuk nilai sesi 1 , dan 6,9 untuk nilai sesi 2 dari analisis yang dibuat, dapat diambil simpulan bahwa hasil yang didapat belum menunjukkan keberhasilan model pembelajaran learning cycle yang dilakukan guru.

Hasil tes prestasi belajar yang merupakan tes lisan dan multiple choice test, memforsir siswa untuk betul-betul dapat memahami apa yang sudah dipelajari. Nilai rata-rata siswa di siklus I sebesar 5,7 pada sesi pertama dan 6,9 pada sesi kedua menunjukkan bahwa siswa setelah menguasai materi yang diajarkan walaupun belum begitu sempurna. Hasil ini menunjukkan peningkatan kemampuan siswa menguasai mata pelajaran.

Hasil tes prestasi belajar di siklus I telah menemukan efek utama bahwa penggunaan metode tertentu akan berpengaruh terhadap prestasi belajar siswa yang dalam hal ini adalah metode learning cycle. Hal ini sesuai dengan hasil meta analisis metode pembelajaran yang dilakukan oleh Soedomo, (dalam Puger, 2004) yang menyatakan bahwa metode pembelajaran yang diterapkan oleh seorang guru berpengaruh terhadap prestasi belajarnya.

Seperti telah diketahui bersama bahwasannya mata pelajaran geografi menitikberatkan pembelajaran pada aspek kognitif, afektif, dan psikomotor sebagai pedoman prilaku kehidupan sehari-hari siswa. Untuk penyelesaian kesulitan yang ada maka penggunaan metode ini dapat membantu siswa untuk berkreasi, bertindak aktif, bertukar pikiran, mengeluarkan pendapat, bertanya, berdiskusi, berargumentasi, bertukar informasi dan memecahkan masalah yang ada bersama dengan anggota kelompok diskusinya. Hal inilah yang membuat siswa 
berpikir lebih tajam, lebih kreatif dan kritis sehingga mampu untuk memecahkan masalah-masalah yang kompleks dan efek selanjutnya adalah para siswa akan dapat memahami dan meresapi mata pelajaran Geografi lebih jauh.

Kendala yang masih tersisa yang perlu dibahas adalah prestasi belajar yang dicapai pada siklus I ini belum memenuhi harapan sesuai dengan tuntutan KKM mata pelajaran geografi di sekolah ini yaitu 7,5 . Oleh karenanya upaya perbaikan lebih lanjut masih perlu diupayakan sehingga perlu dilakukan perencanaan yang lebih matang untuk siklus selanjutnya.

\section{Hasil yang Diperoleh dari Siklus Kedua}

Berdasarkan data yang ditunjukkan pada tabel diatas bahwa nilai dari pre-test dan nilai post-test yang dikumpulkan oleh siswa kelas $X$ IPA 1 SMAN 1 Pusakanagara pada siklus I dapat dihitung dengan cara sebagai berikut.

Nilai Rata-rata Pre-test

$\underline{\mathrm{X} 0} \quad \underline{185}=4,5$

$\mathrm{N} \quad 41$

$$
\begin{aligned}
& \text { Nilai Rata-rata Sesi } 3 \\
& \frac{\mathrm{X} 1}{\mathrm{~N}} \frac{308}{41}=7,5
\end{aligned}
$$

$$
\begin{aligned}
& \text { Nilai Rata-rata Sesi } 4 \\
& \frac{X 2}{N} \quad \frac{343}{41}=8,3
\end{aligned}
$$

Nilai total Rata-rata pada siklus kedua adalah

$\frac{X 3+X 4}{2}=\frac{7.5+8.3}{2}=\frac{15.8}{2}=7.9$
Tabel 1. Rekapitulasi Hasil Penelitian

\begin{tabular}{lllll}
\hline No & Tindakan & & $\begin{array}{l}\text { Rata- } \\
\text { rata }\end{array}$ & $\begin{array}{l}\text { Total } \\
\text { rata- } \\
\text { rata }\end{array}$ \\
\hline 1 & Pre-test & SO & 4.5 & $\begin{array}{l}\text { X0 }= \\
4.5\end{array}$ \\
\hline 2 & Siklus & S1 & 5.7 & $\mathrm{XI}=$ \\
\cline { 2 - 4 } & Pertama & S2 & 6.9 & 6.3 \\
\hline \multirow{2}{*}{3} & Siklus & S3 & 7.5 & XII $=$ \\
\cline { 2 - 4 } & Kedua & S4 & 8.3 & 7.9 \\
\hline
\end{tabular}

Dari hasil pengamatan teman sejawat disampaikan bahwa ada kelebihan-kelebihan yang disampaikan oleh pengamat yaitu bahwa peneliti sudah berpakaian rapi, menggunakan bahasa yang santun, menuntun siswa dengan baik. Hal ini menimbulkan interpretasi bahwa perjalanan penelitian sudah cukup baik. Kelemahan yang disampaikan perlu diberikan analisis yaitu penggunaan waktu yang belum efektif, konstruksi, kontribusi siswa belum maksimal, fakta ini akan dijadikan acuan kebenaran data, validasi, internal yang diambil dari informan di pertanggungjawabkan, validitas eksternal berupa acuan hukum digunakan teori-teori yang mendukung dan reliabilitas data penelitian ini dapat penulis yakini karena hal itu merupakan ketepatan peneliti memilih informan, yaitu teman sejawat. Faktor-faktor yang berpengaruh belum maksimalnya pembelajaran learning cycle pada siklus I ini adalah karena peneliti baru satu kali mencoba model ini. Cara pemecahan masalahnya adalah penyiapan RPP yang lebih baik, lebih berkualitas.

Hasil yang diperoleh dari tes prestasi belajar di siklus kedua menunjukkan bahwa kemampuan siswa dalam mengikuti pelajaran sudah cukup baik. Ini terbukti dari rata-rata nilai siswa mencapai 7,5 pada sesi 3 dan 8,3 pada sesi 4 Hasil ini menunjukkan bahwa metode learning cycle telah berhasil meningkatkan kemampuan siswa menempa ilmu sesuai 
harapan. Learning cycle merupakan model yang cocok bagi siswa apabila guru menginginkan mereka memiliki kemampuan berkreasi, berargumentasi, mengeluarkan pendapat secara lugas, bertukar pikiran, berargumentasi, mengingat penggunaan metode ini adalah untuk memupuk kemampuan intelektual siswa, mendorong siswa untuk mampu menemukan sendiri, menempatkan siswa pada posisi sentral dan mengupayakan agar siswa tidak belajar dengan menghafal tetapi lebih mengeksplorasi kemapuan berpikir siswa berdasarkan hasil pengamatan lapangan.

Hasil penelitian ini ternyata telah memberi efek utama bahwa model yang diterapkan dalam proses pembelajaran berpengaruh secara signifikan terhadap prestasi belajar siswa. Temuan ini membuktikan bahwa guru sudah tepat memilih metode dalam melaksanakan proses pembelajaran karena pemilihan metode merupakan hal yang tidak boleh dikesampingkan. Hal ini sejalan pula dengan temuan-temuan peneliti lain seperti yang dilakukan oleh Inten dan Puger (2004) yang pada dasarnya menyatakan bahwa metode pembelajaran yang diterapkan berpengaruh terhadap prestasi belajar siswa.

$$
\text { Mata pelajaran Geografi }
$$

menitikberatkan kajiannya pada aspek kognitif, afektif dan psikomotor sebagai pedoman atas kemampuan siswa baik pikiran, prilaku maupun visual menempati tempat yang penting karena dapat mengaktifkan siswa secara maksimal. Dari nilai yang diperoleh siswa, lebih setengah siswa mendapat nilai $8,5,13$ siswa memperoleh nilai menengah yaitu 8 . Dari perbandingan nilai ini sudah dapat diyakini bahwa prestasi belajar siswa dapat ditingkatkan dengan penggunaan metode learning cycle.
Melihat perbandingan nilai awal, nilai siklus pertama dan nilai siklus kedua, terjadi kenaikan yang signifikan, yaitu dari rata-rata nilai awal adalah 4,5 naik di siklus pertama menjadi 6,3 dan di siklus kedua naik menjadi 7,9 Kenaikan ini tidak bisa dipandang sebelah mata karena kenaikan nilai ini adalah dari upaya-upaya yang maksimal yang dilaksanakan peneliti demi peningkatan mutu pendidikan dan kemajuan pendidikan khususnya di SMAN 1 Pusakanagara.

\section{E. KESIMPULAN}

Dari keseluruhan rangkaian penelitian diperoleh hasil yang baik dalam upaya meningkatkan kemampuan peserta didik dengan menggunakan model pembelajaran learning cycle. Hal ini disebabkan oleh pola belajar yang tidak monoton sehingga siswa lebih leluasa dalam mengeksplorasi ide-ide atau pun gagasannya. Setiap ide-ide dari peserta didik kemudian secara bersama-sama dielaborasi dan menghasilkan suatu teori yang dibangun berdasarkan pengalaman dari peserta didik. Pola belajar yang melibatkan pengalaman peserta didik menjadi pemicu dalam meningkatkan kemampuan eksplorasi dan hasil belajar peserta didik.

Melihat efektifitas dan keberhasilan pada model belajar learning cycle di SMAN 1 Pusakanagara, penulis menyarankan agar setiap guru dapat menerapkan model pembelajaran yang serupa. Peran aktif dari guru untuk menciptakan banyak model pembelajaran dipercaya dapat merubah suasana kelas yang kaku jadi lebih menyenangkan dan diharapkan dari proses pembelajaran yang menyenangkan dapat meningkatkan hasil belajar peserta didik. 


\section{DAFTAR PUSTAKA}

Burns, A (2010) Doing Action Research in English Language Teaching: A Guide for Practitioners. New York: Routledge.

Dahar, R. W. (2006). Teori-Teori Belajar dan Mengajar. Jakarta: Erlangga

Dasna, I.Wayan.(2005). Kajian Implementasi Model Siklus Belajar (Learning Cycle) dalam Pembelajaran Kimia. Makalah Seminar Nasional MIPA dan Pembelajarannya. FMIPA UM - Dirjen Dikti Depdiknas. 5 September 2005.

Inten, I Gede. (2004). Pengaruh Model Pembelajaran dan Pengetahuan Awal Siswa Terhadap Prestasi Belajar PKn dan Sejarah pada Siswa Kelas II di SMU Laboratorium IKIP Negeri Singaraja. Program Pascasarjana IKIP Negeri Singaraja. Tesis.

Iskandar, S.M. (2005). Perkembangan dan Penelitian Daur Belajar. Makalah Semlok Pembelajaran Berbasis Konstruktivis. Jurusan Kimia UM. Juni 2005.

Lorsbach, A. W. (2002). The learning cycle as a tool for planning science instruction.

Kurnazz. 2008. Using Different Conceptual Change Methods Embedded Within the 5E model:

A Sample Theaching for Heat and Themperature. Journal of Physics Teacher Education Online, 5(2), 3-7.

Mulyani, D. (2013). Hubungan kesiapan belajar siswa dengan prestasi belajar. Konselor, 2(1). Mulyasa, E. (2004). Implementasi Kurikulum 2004 panduan pembelajaran KBK. Bandung: Remaja Rosdakarya.

Peraturan Pemerintah (PP) Republik Indonesia No 19 tahun 2005 Tentang Standar Nasional Pendidikan (SNP).

Peraturan Pemerintah (PP) Republik Indonesia No 32 Tahun 2013 Tentang Perubahan atas Peraturan Pemerintah No 19 Tahun 2005 Tentang Standar Nasional Pendidikan.

Puger, I Gusti Ngurah. (2004). Belajar Kooperatif. Diktat Perkuliahan Mahasiswa Unipas.

Rahayu, S., Prayitno. (2005). Penggunaan Strategi Pembelajaran Learning CycleCooperative Learning 5E (LCC-5E). Makalah Seminar Nasional MIPA dan Pembelajarannya. FMIPA UM - Dirjen Dikti Depdiknas.

Ruhyat. (2018). Meningkatkan Hasil Belajar Melalui Pendekatan Interpersonal Di SMPN 3 Pagaden. Jurnal Edutech, 17(03).

Renner, J. W., Abraham, M. R., \& Birnie, H. H. (1988). The necessity of each phase of the learning cycle in teaching high school physics. Journal of Research in Science Teaching, 25(1), 39-58.

Suharsimi, A. (2006). Prosedur penelitian suatu pendekatan praktik. Jakarta: Rineka Cipta. 